\title{
Karakteristik dan Bentuk Ujaran Bahasa Jepang Orang Osaka Tinjauan Linguistik Kebudayaan
}

\author{
I Wayan Wahyu Cipta Widiastika \\ Wahyucipta60@yahoo.com \\ Denpasar, Indonesia
}

\begin{abstract}
Abstrak
Jurnal ini membahas mengenai karakteristik dan bentuk ujaran bahasa Jepang orang Osaka tinjauan linguistik kebudayaan. Data dikumpulkan melalui interview langsung. Data dianalisis dengan menggunakan teori linguistik kebudayaan menurut Foley (1991), Palmer (1996), dan Riana (2003). Dari data yang ditemukan, karakteristik dan bentuk ujaran bahasa Jepang orang Osaka ditunjukkan dengan kenyamanan berbahasa dengan menggunakan leksikon 'akan', bentuk hormat bahasa Jepang orang Osaka dengan leksikon ( haru), bentuk sopan bahasa Jepang orang Osaka dengan leksikon 'sai de gozaimasu, sou de omasu, sou dasu, sai de gowasu dan sai de goasu', bentuk keakraban berbahasa dengan bentuk 'dou dekka, moukatte makka', dan bahasa Jepang Osaka kasar 'ahou'
\end{abstract}

Kata kunci: karakteristik, bentuk hormat, bentuk sopan, keakraban berbahasa dan bahasa kasar.

In this journal discusses about the characteristics and forms of Japanese speech people Osaka cultural linguistics review. Data are collected through note taking method and direct interview. The data are analyzed with the linguistic theory of culture according to Foley (1991), Palmer (1996), dan Riana (2003). From the data found, the characteristic and the form of speech of Japanese people Osaka is indicated by comfort of language by using the word 'akan', the respect form Japanese language Osaka with the word ( haru), the polite form of Japanese language Osaka with the word 'sai de gozaimasu, sou de omasu, sou dasu, sai de gowasu dan sai de goasu, familiarity of language with the form 'dou dekka, moukatte makka' and Japanese form Osaka rough 'ahou'

Key words: characteristics, respect form, polite form, familiarity of language and rough language.

\section{Pendahuluan}

Bahasa merupakan gambaran kepribadian seseorang. Bahasa juga merupakan gambaran kepribadian bangsa. Artinya, dengan bahasa yang digunakan, seseorang atau suatu bangsa dapat diketahui kepribadiannya. Kepribadian seseorang itu baik atau buruk akan sulit diukur jika mereka tidak mengungkapkan pikiran atau perasaannya melalui tindak bahasa, (Dyah:2008:35). Setiap bahasa yang ada di dunia ini pasti mempunyai karakteristik dan keunikannya masing-masing. Bahasa Jepang sebagai salah satu bahasa asing di
Indonesia yang banyak diminati akhir-akhir ini mempunyai daya tarik yang cukup besar untuk diteliti dan dikembangkan lebih jauh. Setiap daerah di Jepang pasti mempunyai keunikan dan karakteristik bahasanya masing-masing. Baik dalam hal kosakata yang digunakan, gaya berbicara setiap individu, bentuk ujaran, maupun kebudayaannya. Menurut Masuoka (1991:21) salah satu karakteristik bahasa Jepang adalah ketika berbicara kepada lawan bicara dengan bentuk kalimat / ungkapan, bahasa yang digunakan merupakan gambaran perasaan 
pembicara terhadap lawan bicara. Dengan adanya karakteristik bahasa tersebut, masyarakat suatu kelompok merasa mempunyai identitas tersendiri dan ingin dianggap berbeda dengan kelompok lainnya.

Osaka adalah salah satu daerah di Jepang yang mempunyai daya tarik dan karakteristik yang sangat menarik jika dibandingkan dengan daerah lainnya. Orang Osaka sangat berbeda dengan orang Jepang pada umumnya. Orang Osaka akan selalu menggunakan bahasa Jepang Osaka ketika bercakap-cakap di mana pun dan kapan pun, baik dengan sesama orang Osaka maupun dengan orang Jepang non- Osaka. Biasanya, orang Jepang non-Osaka tidak begitu senang dengan orang Osaka yang berbicara dalam bahasa Jepang Osaka karena bahasanya cenderung kasar dan terkadang sulit dimengerti oleh lawan bicara. Leksikon-leksikon seperti : ahou (bodoh) dan akan (tidak boleh) adalah dua buah leksikon bahasa Jepang Osaka yang kurang enak didengar dan dianggap lebih kasar daripada leksikon baka (bodoh) dan dame (tidak boleh) dalam bahasa Jepang standar. Oleh karena itu, hal tersebut dapat dikatakan sebagai salah satu karakteristik bahasa Jepang orang Osaka.

Dari pernyataan tersebut, berikut akan digambarkan fenomena bahasa yang berkaitan dengan karakteristik dan bentuk ujaran bahasa Jepang orang Osaka :

(1) おっちゃんこれ勉強しといてえな

Occhan kore benkyou shitoitee na

'Paman, tolong turunkan harganya ini!'.

(Osaka ben nyuumon, 118)

Dari data di atas bisa dilihat karakteristik dan bentuk ujaran bahasa Jepang orang Osaka dari segi leksikon maupun tata bahasa yang digunakan. Jika dilihat dari segi leksikonnya, kata 'occhan' yang berarti 'paman' dalam bahasa Jepang standarnya adalah 'ojisan'. Kemudian leksikon 'benkyou' dalam bahasa Jepang Osaka mempunyai makna menurunkan harga 'ne wo sageru' atau 'makeru' yang berarti kalah, akan tetapi dalam bahasa Jepang standarnya bermakna 'belajar'. Dari fenomena bahasa di atas, jika bentuk ujaran tersebut dipadankan ke dalam bahasa Jepang standar akan menjadi 'ojisan, kore, makete oite yo'

Orang Osaka mempunyai kebiasaan suka menawar saat berbelanja. Mereka biasanya menggunakan ungkapan 'benkyou shitoitee $n a$ ' untuk menawar harga sekaligus menunjukkan identitas asal mereka. Mereka juga menggunakan bahasa Jepang Osaka yang intonasinya lembut ketika bercakap-cakap. Hal itu dikarenakan orang Osaka sangat senang bercakap cakap, serta bahasa yang digunakannya pun sangat hidup dan menyenangkan. Oleh karena itu, tidak heran ada banyak pelawak-pelawak ataupun komedian (manzai) yang terkenal di seluruh Jepang berasal dari Osaka. Hal tersebutlah yang merupakan keunikan dan daya tarik tersendiri bahasa Jepang Osaka yang menjadi latar belakang dalam jurnal ini.

\section{Bahan dan Metode}

Data-data dalam penelitian ini berasal dari data tulis yang digunakan oleh penutur bahasa Jepang Osaka dalam percakapan sehari-hari. Data dikumpulkan melalui note taking dan wawancara langsung untuk memastikan kebenaran data. Data dianalisis dengan pendekatan teori linguistik kebudayaan Palmer (1996), dan Riana (2003). Linguistik kebudayaan sebagai salah satu perspektif teoritis dalam linguistik kognitif yang mengkaji hubungan kovariatif antara bahasa dan kebudayaan yang dianut satu kelompok masyarakat. Titik incar utama yang menjadi sasaran pemerian dalam linguistik kebudayaan adalah analisis makna bahasa sebagai cerminan makna budaya dengan tujuan untuk mengetahui pemahaman budaya warga kelompok masyarakat bersangkutan dalam memandang dunia (Palmer, 1996:10-26; Foley, 1991:5). Bertalian dengan itu, menurut Riana (2003), linguistik kebudayaan merupakan sebuah cakrawala baru dalam kajian linguistik karena bahasa yang digunakan dalam realitas kehidupan satu kelompok masyarakat tidak saja dipahami sebagai sebuah fenomena 
linguistik, tetapi juga dimaknai sebagai sebuah fenomena sosial dan fenomena budaya. Dalam kaitan dengan peran bahasa sebagai fenomena sosial dan fenomena budaya, fokus utama yang menjadi sasaran pemerian dalam kajian linguistik kebudayaan adalah analisis perilaku bahasa dan pola penggunaanya dalam konteks sosial dan konteks budaya. Dengan demikian, analisis linguistik kebudayaan lebih banyak bermuara pada penjaringan arti, penggalian makna dan penemuan nilai di balik penggunaan bahasa dalam satu realitas kehidupan satu guyub tutur dengan tujuan untuk mengetahui cara pandang mereka tentang dunia, baik dunia yang secara faktual terjadi maupun dunia simbolik.

\section{Hasil dan Pembahasan}

Berikut dipaparkan beberapa karakteristik dan bentuk ujaran bahasa Jepang orang Osaka yang sekaligus mewakili kebudayaan Osaka:

\subsection{Kenyamanan Berbahasa}

Jika berbicara mengenai kenyamanan berbahasa, orang Osaka bisa disebut sebagai orang Jepang yang cenderung memperlihatkan identitas diri mereka. Dengan menggunakan bahasa Jepang Osaka, secara tidak langsung lawan bicara akan mengetahui asal dari lawan tuturnya. Bahasa Jepang Osaka mempunyai keanekaragaman bentuk. Leksikon 'akan' dan 'ikan' yang berarti 'tidak boleh' adalah dua buah leksikon yang mewakili karakteristik budaya Jepang orang Osaka. Orang Osaka merasa lebih nyaman menggunakan leksikon tersebut dengan alasan agar mereka lebih leluasa mengungkapan emosi dan perasaannya kepada lawan bicara.

\section{(3-1) Kenyamanan berbahasa dengan bentuk ( te ikana akan) \\ 我々が文化を見る目を変えていかなあかん わけですね. \\ Wareware ga bunka wo miru me wo kaete ikana akan wake desu ne.}

'Kami punya alasan harus mengubah cara mata kami melihat budaya'.

(Satou, Osaka ben no sekai, 1995:21)

Tabel 3-1: Perbandingan bahasa Jepang Osaka dan bahasa Jepang standar

\begin{tabular}{lll}
\hline Bahasa & Bahasa & Arti \\
Jepang Osaka & Jepang Standar &
\end{tabular}

\begin{tabular}{lll}
$\begin{array}{l}\text { Kaete ikana } \\
\text { akan. }\end{array}$ & $\begin{array}{l}\text { Kaerana kereba } \\
\text { narimasen. }\end{array}$ & $\begin{array}{l}\text { Harus } \\
\text { mengubah }\end{array}$ \\
\hline
\end{tabular}

Dari data (3-1) 'kaete ikana akan' mempunyai makna 'harus merubah' yang masing-masing terdiri dari 3 leksikon : 'kaete' berarti (mengubah) yang berasal dari kata kerja bentuk kamus 'kaeru' yang berubah bentuk menjadi bentuk ( te) menjadi 'kaete', kemudian 'ikana' pada mulanya berasal dari 'ikanai' (tidak pergi) yang akhiran ( $\sim$ i)-nya dihilangkan, sehingga 'ikana' dalam konteks ini mempunyai arti 'tidak boleh'. Dan terakhir leksikon 'akan' merupakan salah satu karakteristik bahasa Jepang orang Osaka yang mempunyai arti 'tidak boleh' adalah leksikon yang sering digunakan oleh orang Jepang Osaka untuk melarang seseorang untuk melakukan sesuatu. Dari perubahan bentuk di atas, dapat dilihat karakteristik bahasa Jepang orang Osaka yang menggunakan leksikon 'akan' untuk menyatakan bentuk keharusan dalam sebuah kalimat yang secara tidak langsung mencerminkan kenyamanan berbahasa mereka.

\subsection{Bentuk Hormat ( haru )}

Bahasa Jepang Osaka tidak semuanya bentuknya informal, akan tetapi bahasa Jepang Osaka juga mempunyai kesamaan dengan bahasa Jepang standar pada umumnya, yakni mempunyai bentuk hormat. Untuk menyatakan rasa hormat kepada orang lain, dalam bahasa Jepang Osaka digunakan bentuk ( haru) yang akan dipaparkan sebagai berikut :

\section{( 3-2 ) Makan (tabeharu )}


タイのある地域ではどうですかもう御飯食 べはりましたかとええもう御飯頂きました。

Tai no aru chiiki de wa dou desu ka mou gohan tebeharimashita ka to ee mou gohan itadakimashita.

'Di suatu daerah di Thailand, bagaimanakah ? apakah sudah makan ? ya, saya sudah makan'.

(Satou, Osaka ben no sekai, 1995:17)

Tabel 3-2 : Perbandingan bahasa Jepang Osaka dan bahasa Jepang standar

\begin{tabular}{lll}
\hline Bahasa & Bahasa & Arti \\
Jepang Osaka & Jepang Standar & \\
Tabeharima & Meshiagarima & Sudah \\
shita ... & shita ... & makan. \\
\hline
\end{tabular}

Dari data (3-2) bisa dilihat bentuk hormat 'tabeharimashita' yang pada awalnya berasal dari kata kerja bahasa Jepang standar bentuk kamus 'taberu' yang akhiran ( $\sim r u)$-nya dihilangkan, dan ditambahkan dengan ( haru), kemudian berubah bentuk menjadi bentuk lampau 'mashita'. Biasanya kata kerja (makan) 'tabeharimashita' digunakan oleh orang Osaka untuk menunjukkan rasa hormat kepada orang lain. Akan tetapi, dalam bahasa Jepang standar juga ada kata kerja 'makan' yang digunakan untuk menunjukkan rasa hormat kepada orang lain, yakni 'meshiagaru'. Ketika mempersilahkan orang lain untuk menyantap makanan, biasanya digunakan ungkapan hormat 'douzo goyukkuri omeshiagari kudasai' yang artinya : 'silahkan makan pelan-pelan'. Dari hal tersebut dapat dilihat variasi bentuk leksikon bahasa Jepang Osaka dan bahasa Jepang standar yang masingmasing mempunyai karakteristik yang berbedabeda.

\subsection{Bahasa Sopan (teinei na kotoba)}

Dalam bahasa Jepang orang Osaka juga ada beberapa leksikon yang digunakan untuk menunjukkan rasa hormat kepada orang lain. Biasanya leksikon ini berupa bahasa Jepang Osaka sopan yang biasanya digunakan oleh para pedagang untuk menunjukkan rasa hormat kepada pelanggan, seperti bentuk : sai de gozaimasu, sou de omasu, sai de gowasu, sai de goasu, dan sou dasu, yang akan digambarkan sebagai berikut :

\section{(3-3) Teinei na kotoba}

言葉ではそうでございますというのを さいでございますと丁寧に言いますねとこ ろが近代大阪弁ではそうでおますで 済ませますまた同じことを船場言葉では さいでごわすあるいはさいでごあすと 言うような言い方をしますが近代大阪弁 はそうだすで済ませておりますね。

Kotoba de wa sou gozaimasu to iu no wo sai de gozaimasu to teinei ni iimasu ne, tokoro ga, kindai oosaka ben de wa sou de omasu de sumasemasu, mata onaji koto wo funaba kotoba de wa sai de gowasu, aruiwa sai de goasu to iu you na iikata wo shimasu ga, kindai oosaka ben wa sou dasu de sumasete orimasu ne.

'Dalam ungkapan kata sou de gozaimasu, akan menjadi lebih sopan jika diucapkan sai de gozaimasu. Namun dalam dialek osaka modern, bisa diucapkan dengan sou de omasu. Dan dalam bahasa yang sama yang digunakan di dermaga, bisa diucapkan dengan sou dasu yang digunakan untuk mengakhiri pembicaraan'. (Satou, Osaka ben no sekai, 1995:62)

Tabel 3-3 : Perbandingan bahasa Jepang Osaka dan bahasa Jepang standar

$\begin{array}{lll}\text { Bahasa } & \text { Bahasa } & \text { Arti } \\ \text { Jepang Osaka } & \text { Jepang Standar } & \end{array}$

\begin{tabular}{lll}
\hline Sai de & Sou de & Begitu ya. \\
gozaimasu. & gozaimasu. & \\
Sou de omasu. & Sou de & Begitu ya. \\
& gozaimasu. &
\end{tabular}




$\begin{array}{lll}\text { Sou dasu. } & \begin{array}{l}\text { Sou de } \\ \text { gozaimasu. }\end{array} & \text { Begitu ya. } \\ \begin{array}{l}\text { Sai de } \\ \text { gowasu. }\end{array} & \begin{array}{l}\text { Sou de } \\ \text { gozaimasu. }\end{array} & \text { Begitu ya. } \\ \text { Sai de goasu. } & \begin{array}{l}\text { Sou de } \\ \text { gozaimasu. }\end{array} & \text { Begitu ya. } \\ & \end{array}$

Dari data (3-3) bisa dilihat bentuk dan variasi bahasa Jepang sopan yang digunakan oleh orang Osaka. Dalam bahasa Jepang standar pada umumnya, untuk menanggapi atau menyetujui maksud dari lawan bicara biasanya digunakan ungkapan 'sou desu' yang berarti 'begitu ya'. Ungkapan 'sou desu' berubah menjadi 'sou de gozaimasu' apabila digunakan untuk menyatakan hormat kepada orang lain dalam bahasa Jepang standar, dan berubah menjadi 'sai de gozaimasu' dalam bahasa Jepang Osaka. Dalam bahasa Jepang Osaka modern, ungkapan 'sai de gozaimasu' berubah menjadi 'sou de omasu' atau 'sou dasu'. Bahasa Jepang Osaka mempunyai banyak variasi leksikon dan penggunaan yang berbeda-beda tergantung tempat dan waktu pemakaiannya, seperti ungkapan 'sai de gowasu' dan 'sai de goasu'. Kedua leksikon tersebut merupakan dua buah ungkapan sopan bahasa Jepang Osaka yang hanya digunakan di daerah dermaga. Karena Osaka dikenal sebagai daerah perdagangan, biasanya ungkapan sopan tersebut digunakan oleh para pedagang di Osaka untuk menunjukkan rasa hormat kepada pembeli.

\subsection{Keakraban Berbahasa}

Ungkapan keakraban berbahasa ini dapat dikatakan sebagai salah satu karakteristik bahasa Jepang orang Osaka yang paling populer karena banyak orang Jepang di daerah Osaka yang bekerja dan berprofesi sebagai pedagang. Mereka menggunakan ungkapan ini sebagai salam keakraban dengan pedagang lainnya. Ketika ditanya apakah mendapat untung atau tidak, secara tidak langsung lawan bicara akan merespon ungkapan ini dengan 'bochi bochi de $n a$ ' yang artinya 'lumayan' dalam bahasa Jepang standar 'maa maa desu'. Berikut akan dipaparkan mengenai bentuk keakraban berbahasa orang Osaka yang pada umumnya digunakan kepada sesama pedagang di daerah Osaka :

(3-4) Keakraban berbahasa (dou dekka, moukatte makka)

例えば大阪の一部商売人なんかどうでっか 儲かってまっかと挨拶しますこれはやっぱ り大阪の商人の文化の表れがその挨拶 の言葉になっている

Tatoeba oosaka no ichibu shoubai nin nanka dou dekka moukatte makka to aisatsus himasu kore wa yappari osaka no shounin no bunka no araware ga sono aisatsu no kotoba ni natte iru

(Satou, Osaka ben no sekai,1995:17)

'Contohnya, bagian dari pedagang yang ada di Osaka, memberi salam seperti : bagaimana ? apakah mendapatkan keuntungan ?, ini muncul karena memang budaya pedagang yang ada di Osaka, sehingga itu menjadi kata untuk salam'.

Tabel 3-4 : Perbandingan bahasa Jepang Osaka dan bahasa Jepang standar

\begin{tabular}{lll}
\hline $\begin{array}{l}\text { Bahasa } \\
\text { Jepang Osaka }\end{array}$ & $\begin{array}{l}\text { Bahasa } \\
\text { Jepang Standar }\end{array}$ & Arti \\
\hline Dou dekka. & Dou desu ka. & Bagaimana?. \\
$\begin{array}{l}\text { Moukatte } \\
\text { Makka. }\end{array}$ & Moukarimasu & $\begin{array}{l}\text { Apakah dapat } \\
\text { untung?. }\end{array}$ \\
\hline
\end{tabular}

Dari data (3-4) bisa dilihat bentuk ungkapan 'dou dekka, moukatte makka'. Ungkapan tersebut pada mulanya berasal dari bahasa Jepang standar 'dou desu $k a$, moukarimasu $\mathrm{ka}$ ' yang bermakna : 'bagaimana kah, apakah mendapatkan keuntungan ?'. Dari ungkapan tersebut, terjadi perubahan bentuk kopula ( desu ka) menjadi ( dekka) dalam bahasa Jepang Osaka. Kata kerja 'moukarimasu' berasal dari kata kerja bentuk kamus 'moukaru' yang berubah bentuk menjadi bentuk ( te) 'moukatte' dan bentuk ( masu ka) berubah 
bentuk menjadi 'makka' dalam bahasa Jepang Osaka. Ungkapan tersebut tidak hanya bermakna salam keakraban di antara para pedagang, akan tetapi juga bermakna menanyakan perkembangan dagangan lawan bicara secara tidak langsung.

\subsection{Bahasa Kasar (ranbou na kotoba)}

Bahasa Jepang adalah salah satu bahasa yang paling banyak mempunyai variasi leksikon daripada bahasa asing lainnya. Dalam bahasa Jepang standar, leksikon 'bodoh' mempunyai banyak variasi bentuk, seperti : baka, nou tarin dan apontan. Sedangkan dalam bahasa Jepang Osaka, leksikon 'bodoh' berarti : aho, boke, kasu dan donkusai. Dalam sub bab ini hanya memfokuskan pada dua leksikon, yakni : baka dan aho. Leksikon 'aho' bagi orang Osaka adalah hal yang biasa, akan tetapi leksikon 'aho' bagi orang Tokyo adalah suatu leksikon yang sangat kasar dan tidak enak untuk didengar. Berikut akan digambarkan perbedaan dan karakteristik leksikon 'baka' dan 'aho' :

\section{( 3-5 ) Baka dan Aho (bodoh)}

東京でバカって言ったらなんだってなるん です大阪でアホーって 言われたらアホ ちゃいまんねんパーでんねんあるいはアホ にアホと言うアホはほんまのアホやでてな 事を言って相手をちゃらかす

Tokyo de baka tte ittara nanda tte naru $n$ desu oosaka de ahoo tte iwaretara aho chaiman nen paaden nen aruiwa aho ni aho to iu aho wa honma no aho ya de te na koto wo itte aite wo charakasu

'Di Tokyo, kalau bilang 'kamu bodoh (baka)', akan menjadi 'apa kamu bilang (nanda) ?', akan tetapi kalau bilang 'kamu bodoh (aho)' di osaka, lawan bicara akan menjawab 'aku tidak bodoh (aho chaiman nen), bodoh ya (paaden nen), atau apabila orang bodoh mengatakan bodoh 'aho' kepada orang bodoh, artinya menyindir orang lain dengan mengatakan sesuatu hal yang bodoh'.
(Satou, Osaka ben no sekai, 1995:95)

Tabel 3-5 : Perbandingan bahasa Jepang Osaka dan bahasa Jepang standar

\begin{tabular}{lll}
\hline Bahasa & Bahasa & Arti \\
Jepang Osaka & Jepang Standar &
\end{tabular}

\begin{tabular}{lll}
\hline $\begin{array}{l}\text { Chaiman } \\
\text { nen. }\end{array}$ & Chigaimasu yo. & $\begin{array}{l}\text { Bukan, } \\
\text { berbeda lho. }\end{array}$ \\
Paaden nen. & Baka desu yo. & Bodoh lho.
\end{tabular}

Honma. Hontou. Sungguh.

Aho ya de. Baka desu ne. Bodoh ya.

Dari data (3-5) dapat dilihat perbedaan kebudayaan antara orang Osaka dan orang Tokyo. Orang-orang Osaka biasanya cenderung santai dalam menanggapi sesuatu dan suka bercanda ketika bercakap-cakap. Berbeda dengan orang Tokyo yang bersikap dingin dan tidak begitu suka bercanda seperti halnya orang Osaka. Leksikon yang berarti 'bodoh' dalam bahasa Jepang Osaka tidak hanya leksikon 'aho, boke, 'kasu' ataupun donkusai'. Namun ada juga leksikon 'paaden nen' yang berarti 'bodoh ya' pada data tabel 3-5. Leksikon tersebut juga merupakan salah satu bagian dari bahasa Jepang Osaka. Bagi orang Osaka sendiri, leksikon tersebut hanya dianggap leksikon biasa, akan tetapi bermakna kasar untuk orang Tokyo. Perbedaan tersebut terjadi karena di daerah Osaka dikenal sebagai daerah perdagangan yang masyarakatnya mayoritas sangat suka bercakapcakap dengan menggunakan bahasa Jepang Osaka. Berbeda halnya dengan Tokyo sebagai kota metropolitan sibuk yang hampir semua masyarakatnya dikenal bersikap dingin dan tidak begitu suka berkomunikasi. Dari hal tersebut muncul perbedaan yang sangat signifikan antara orang Osaka dan orang Tokyo jika dilihat dari 
segi penggunaan bahasa, tingkah laku penutur serta kebudayaannya.

\section{Simpulan}

Orang Osaka cenderung menggunakan leksikon seperti : 'akan' maupun ' ikan' untuk mengungkapkan emosi dan perasaan ketika berbicara. Bahasa Jepang Osaka juga sama halnya dengan bahasa Jepang standar yang memiliki bentuk formal dan informal, serta tingkatan berbahasa yang berbeda, seperti : bentuk bahasa hormat, sopan, biasa dan kasar. Orang Osaka sangat terkenal dengan bahasanya yang kasar. Leksikon 'ahou' (bodoh) menjadi salah satu ikon bahasa Jepang Osaka karena leksikon tersebut sering terdengar dalam acara komedian maupun percakapan sehari-hari orang Osaka. Orang Osaka juga dikenal sebagai orang Jepang yang sangat suka bercakap-cakap sehingga mudah mengakrabkan diri dengan orang lain. Karena karakter dan sifat orang Osaka yang sangat suka bercakap-cakap, tidak heran banyak pelawak maupun komedian yang terkenal di seluruh Jepang yang berasal dari daerah Osaka.

\section{Daftar Pustaka}

Dyah, Wahyuning. 2018. Faktor-Faktor Yang Mempengaruhi Pemilihan Ungkapan Perintah Bahasa Jepang dalam Teks Percakapan : Kajian kesantunan berbahasa. Linguistika, maret 2018 p-ISSN: 0854-9613. Vol. 48. No. 25

Hani, Wahyuningtias. 2017. Partikel Akhir Kalimat bahasa Jepang Dan Bahasa Indonesia. Linguistika, maret 2017 ISSN: 08549613. Vol. 24. No. 46

Masuoka, Takeshi.1991.Modality no Bunpou. Tokyo: Kuroshioshuppan

Palmer, G. B. 1996. Toward a Theory of Cultural Linguistics. Austin: The University of Texas Press.

Satou, Osaka Ben Purojekuto, NHK. 1995. Osaka ben no sekai. Japan: Keiei insatsu kabushiki gaisha.

Sudaryanto.1988b. Metode Linguistik Bagian Kedua. Metode dan Aneka Teknik
Pengupulan data. Yogyakarta: Gadjah Mada University Press.

Sudaryanto.1993. Metode dan Aneka Teknik Analisis Bahasa. Pengantar Penelitian Wahana Kebudayaan secara Linguistis. Yogyakarta: Duta Wacana University Press.

Riana, Ketut. 2003. 'Linguistik Budaya : Kedudukan dan Ranah Pengkajiannya'. Pidato Pengukuhan Jabatan Guru Besar Tetap Dalam Bidang Ilmu Linguistik Budaya. Denpasar : Universitas Udayana. 